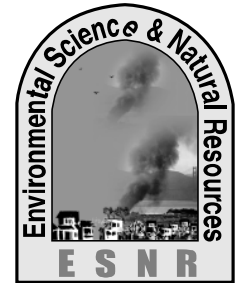

\title{
A Survey on Medicinal Plants used by the Folk Medicinal Practitioners in Tangail Sadar Upazilla, Tangail, Bangladesh
}

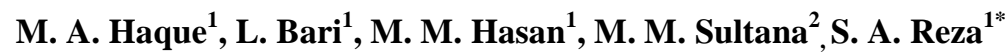 \\ ${ }^{1}$ Department of Food Technology and Nutritional Science, \\ Mawlana Bhashani Science and Technology University, Santosh, Tangail-1902 \\ ${ }^{2}$ Vrije University of Brussels, Brussels, Belgium
}

\begin{abstract}
Medicinal plants form an important and often the only component in the formulations used by the folk medicinal practitioners of Bangladesh for treatment of various ailments. Folk medicinal practitioners, otherwise known as Kavirajes, perform an integral role in the delivery of primary health-care to substantial segments of both rural and urban population of the country. To get a comprehensive view of the medicinal plants of Bangladesh, it is therefore important to conduct extensive interviews of individual Kavirajes of both urban and rural areas. Towards obtaining such comprehensive information, the present ethno-medicinal survey was conducted among the Kavirajes of 15 randomly surveyed villages of Tangail Sadar Upazila in Bangladesh to document their use of medicinal plants and the ailments treated by those plants. Information was obtained from the Kavirajes with the help of a semi-structured questionnaire and the guided field-walk method. The results showed that the Kavirajes of the 11 villages surveyed used a total of 55 plants distributed into 35 families in their formulations. The Mimoceseae family provided 4 plants, while the Acanthaceae, Liliaceae, Lamiaceae and Fabaceae families provided 3 plants each. Mainly leaves were used for this purpose. Other plant parts roots and stems were also used. The various ailments treated included gastrointestinal disorders, cuts and wounds, fever, respiratory tract disorders, snake bites, pain, menstrual problems, physical weakness, diabetes, mental disorders, cardiovascular disorders, skin disorders, chicken pox, burns, spermatorrhea, bone fractures and cattle ailments.
\end{abstract}

Key Words: Ethno-medicinal study, Kavirajes, Medicinal plants, Tangail sadar

\section{Introduction}

Bangladesh is a developing country. The majority of the population lives in rural areas do not use modern health care facilities because of inadequate road transport, lack of allopathic doctors and absence of hospitals or clinics, non-affordability to buy modern medicines, and age-old dependency on folk medicinal practitioners, who are locally known as Kavirajes. The Kavirajes depend primarily on medicinal plants for treatment of various ailments. The knowledge attained by Kavirajes are usually kept within the family and passed from generation to generation. Over the centuries, the Kavirajes thus have attained considerable expertise on the use of medicinal plants for treatment of a diverse variety of ailments. Bangladesh has over 86, 000 villages and each village has one or more practicing Kavirajes.

Kavirajes also practice in the urban areas including the capital city of Dhaka, where they have a substantial clientele too. We had been conducting ethno-medicinal surveys among the Kavirajes of various areas and tribes of Bangladesh for the last year. Any comprehensive knowledge of folk medicinal plants are noticeably absent in Bangladesh. Yet such knowledge is important, because Bangladesh has over 5,000 floral species a considerable number of which are used by the Kavirajes. Towards the fulfilment of this gap in our ethno-medicinal knowledge on use of local plants, surveys have been conducted in various villages and among various tribes. Previous studies indicated that the different Kavirajes of different villages in most cases do not use similar plants or combination of plants for treatment of any specific ailment (Rahmatullah et al., 2009; Hossan et al., 2009; Hanif et al., 2009; Nawaz et al., 2009; Rahmatullah et al., 2010; Mollik et al., 2010; Rahmatullah et al., 2010).

Since modern medicine has been found lacking in a number of aspects like side-effects, development of resistance and high prices, the empirical knowledge of the Kavirajes can go a long way towards development of newer and more efficacious drugs. About $64 \%$ of the total global population reportedly remains dependent on traditional medicine and medicinal plants for provision of their health-care needs (Cotton, C.M., 1996). Considering the overall situation the research was conducted to investigate the medicinal plant and their using in the area mentioned the title.

\section{Materials and Methods}

Tangail Sadar is an Upazila of Tangail District in the Division of Dhaka, Bangladesh. Tangail Sadar is located at $24^{\circ} 15^{\prime} 00^{\prime \prime} \mathrm{N}$ longitude and $89^{\circ} 55^{\prime} 00^{\prime \prime} \mathrm{E}$ longitude. It has 69783 units of house hold and total area $334.26 \mathrm{~km}^{2}$. As of the 2012 Bangladesh census, Tangail Sadar has a population of 521104 of which males constitute $51.05 \%$ of the population, and females $48.95 \%$. Tangail Sadar has an average literacy rate of $36.4 \%$ ( $7+$ years), and the national average of $32.4 \%$. Tangail Sadar has 16 Unions/Wards, 353 Mauzas/Mahallas, and 277 
villages. The villages surveyed namely Binnafore, Dannya, Mogra, Gala, Santosh, Shakrail, Katuli, Porabari, Baghil, Gharinda, Silimpur, Hugra,
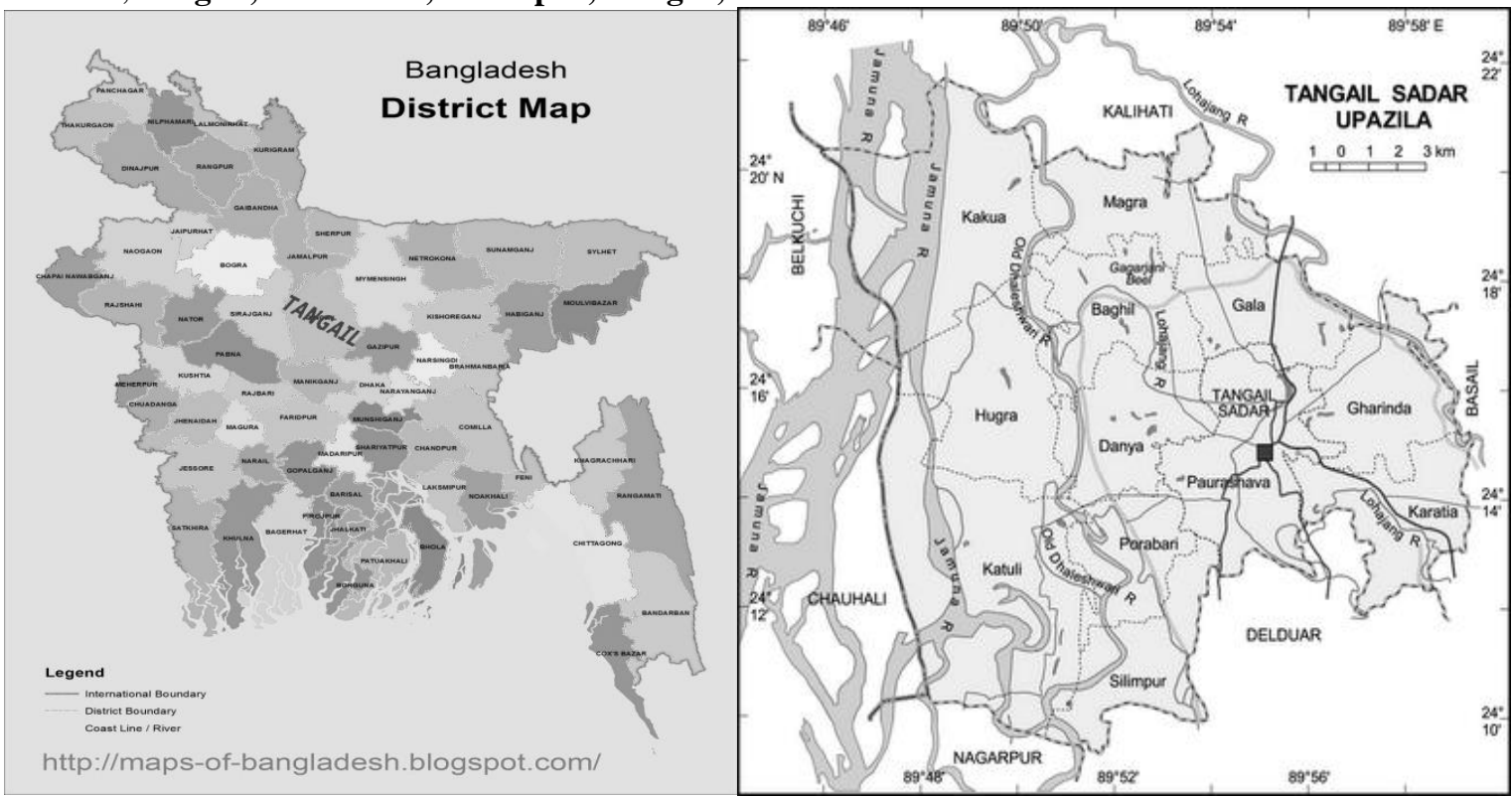

Figure 1: Location Map of Survey area, Tangail Sadar, Tangail District, Bangladesh.

During the survey period, several field trips were undertaken to the study area and 15 famous traditional practitioners (Table 1) who regularly Table 1: Names and addresses of Kavirajes
Belta, Akurtakur Para and Kakua. Agriculture $(35.74 \%)$ is the main occupation of these villagers.

\begin{tabular}{|l|l|l|l|}
\hline Name of Kaviraj & \multicolumn{1}{|c|}{ Address } & Name of Kaviraj & Address \\
\hline Md. Ahsanullah & Binnafore, Tangail & Md. Rahman Miah & Belta, Tangail \\
\hline Ramprassad Saha & Dannya, Tangail & Khabir Uddin & Gharinda, Tangail \\
\hline Md. Tamijuddin & Mogra, Tangail & Md. Ajmal Khan & Hugra, Tangail \\
\hline Sultan Miah & Gala, Tangail & Md. Siraj Ahmed & Katuli, Tangail \\
\hline Md. Mahmud & Kakua, Tangail & Md. Atta Talukder & Porabari, Tangail \\
\hline Md. Dudu Miah & Akurtakur Para, Tangail & Md. Mumtaz Uddin & Baghil, Tangail \\
\hline Md. Abdul Miah & Santosh, Tangail & Md. Amir Khan & Silimpur, Tangail \\
\hline Md. Abul Mia & Shakrail, Tangail & & \\
\hline
\end{tabular}

The Kavirajes were informed about the purpose of the survey and consent taken for dissemination of the obtained data both nationally and internationally. Surveys were conducted with the help of a semi-structured questionnaire and the guided field walks method as described by Martin (1995) and Maundu (1995). In this method, one or more Kavirajes took the interviewers on guided field-walks through areas from where they collected their medicinal plants. Plants were pointed out to the interviewers along with provision of local names and description of their uses. Plant used local plant resources for their practices were selected. specimens as pointed out by the Kavirajes were collected on the spot, dried, and brought to Bangladesh National Herbarium for identification.

\section{Results}

The recorded Information on 55 Plants Species, used commonly as remedies for various diseases are listed with their Family, Botanical name, Local name, Plant part used and their therapeutic use in Tangail Sadar Upazila (Table 2). 
Table 2: Local status of Medicinal plants (wild) in Tangail Sadar

\begin{tabular}{|c|c|c|c|c|c|}
\hline SL & Botanical Name & Local name & Family & Part used & Local uses \\
\hline 1 & $\begin{array}{l}\text { Abelmoschus moschatus (L.) } \\
\text { Medic. }\end{array}$ & Kalokasturi & Malvaceae & Seed, Bark & DTD, STD \\
\hline 2 & Abroma augusta L. & Ulatkambal & Sterculiaceae & Root, Bark & ND, DTD \\
\hline 3 & Abutilon indicum (L.) Sw. & Potari & Malvaceae & Root, Leaves & STD \\
\hline 4 & Acacia farnesiana (L.) Willd. & Guyababla, Belati Babul & Mimosaceae & Bark, Leaves & STD, RP, DTD \\
\hline 5 & Acalypha indica $L$. & Muktajhuri & Euphorbiacee & Leaves, Plants & $\mathrm{RP}, \mathrm{AP}$ \\
\hline 6 & Adenanthera pavoninal. & Rakta Kambal & Mimosaceae & Seeds, Roots & MSD \\
\hline 7 & Adhatoda zeylanica medic. & Basak & Acanthaceae & Root, Bark, Leaves & STD, RP \\
\hline 8 & Adiantum philippense $L$. & Goyalelata, Kalijhant & Adiantaceae & Whole plant & DTD, Rf \\
\hline 9 & Aganosma dichotoma k. Schum. & Malati, Gandhomalati & Apocynaceae & Leaves, Flower & SD, ED \\
\hline 10 & Albizzia lebbeck (L.) Benth. & Sirish, KalaKoroi & Mimosaceae & Bark, Seed, Leaves & $\mathrm{DP}, \mathrm{ND}, \mathrm{SD}$ \\
\hline 11 & Alpinia nigra (gaertn.) Burtt. & Jangli Ada, Tara & Zingiberaceae & Roots & $\mathrm{ND}, \mathrm{Rf}$ \\
\hline 12 & Amaranthus spinosus $L$. & Katanotey, Katadenga & Amaranthaceae & Roots & GD, DTD, BP \\
\hline 13 & $\begin{array}{l}\text { Andrographis paniculata (Burm. } \\
\text { F.) Wall. Ex Ness. }\end{array}$ & Kalomegh, Kalamegh & Acanthacea & Whole plant & $\mathrm{HD}, \mathrm{DTD}, \mathrm{Db}$ \\
\hline 14 & Asclepias curassavica L. & Kakturi, Ban Kapas & Asclepiadaceae & Root, Leaves & AC, DTD, STD \\
\hline 15 & Asparagus racemosus $L$. & Satamuli & Liliaceae & Roots & $\mathrm{ND}, \mathrm{HD}, \mathrm{RD}$ \\
\hline 16 & Averrhoa bilimbi L. & Bilimbi, Belembu & Averrhoaceae & Fruits & HD, Vitc-d \\
\hline 17 & Bacopa monniera (L.) Pennel. & Dhupkamini & Scrophulariaceae & Leaves & RH, ND, RP \\
\hline 18 & Barlaria strigosa willd. & Dasi & Acanthaceae & Roots, Leaves & DP, SD, AS \\
\hline 19 & Boesenbergia longiflora kuntze. & Pati pata & Zingiberaceae & Roots & $\mathrm{ND}, \mathrm{RP}$ \\
\hline 20 & Brassica nigra (L.) Koch. & Kalo Sarisha & Brassicaceae & Seeds & $\mathrm{ND}, \mathrm{Rf}$ \\
\hline 21 & Capsicum frutescence $L$. & Lanka-marich & Solanaceae & Leaves, Fruits & PB, DTD, ED \\
\hline 22 & Cayratia trifolia (L.) Domin. & Amal-lata & Vitaceae & Whole plant & PB, DTD \\
\hline 23 & Dalbergia volubilis roxb. & Ankilata, Barasirkath & Fabaceae & Roots, Leaves & STD, PB \\
\hline 24 & Datura metel L. & Dhutra, Dhutura & Solanaceae & Leaves, Seeds & $\mathrm{AB}, \mathrm{AF}, \mathrm{RP}, \mathrm{DTD}$ \\
\hline 25 & Derris indica (lamk.) Bennet. & Karanija,Kanji & Fabaceae & Roots, Leaves & PB, Rf, SD \\
\hline 26 & Desmodium gangeticum (L.) Dc. & Salpani, Chalani & Fabaceae & Roots & DTD, HD, CD \\
\hline 27 & Dimocarpus longan lamk. & Ashphal & Sapindaceae & Fruits, Seeds & RH, ND \\
\hline 28 & Drynaria quercifolia (l.) J. Sm. & Pankhiraj, Pankha & Drynariaceae & Whole plant & $\begin{array}{l}\text { ND, DTD, SD, } \\
\text { RD }\end{array}$ \\
\hline 29 & Embelia ribes Burm. F. & Biranga & Myrsinaceae & Fruits, Roots & SD, DTD, PB \\
\hline 30 & Enhydra fluctuans lour. & Helencha & Asteraceae & Whole plant & RP, ND, SD, HD \\
\hline 31 & Entada pursaetha dc. & Gilagach, Gilla & Mimosaceae & Seeds & PB \\
\hline 32 & Euphorbia tirucalli L. & Lanka Sij & Euphorbiaceae & Whole plant & $\mathrm{SD}, \mathrm{RD}, \mathrm{ND}$ \\
\hline 33 & Ficus religiosa $L$. & Aswatha, Pipal & Moraceae & Fruits, Seeds & $\mathrm{RP}, \mathrm{HD}, \mathrm{RD}$ \\
\hline 34 & Flacourtia indica (Burm.f.) Merr. & Boichi, Benchi & Flacourtiaceae & Bark, Roots & $\mathrm{HD}, \mathrm{SD}, \mathrm{Rf}$ \\
\hline 35 & Gloriosa superba L. & Ulatchandal & Liliaceae & Roots, Leaves & $\mathrm{SD}, \mathrm{AP}$ \\
\hline 36 & $\begin{array}{l}\text { Glycosmis pentaphylla (retz.) A. } \\
\text { Dc. }\end{array}$ & Datmajan, Matmati & Rutaceae & Leaves & $\mathrm{HD}, \mathrm{Rf}$ \\
\hline 37 & Hedyotis corymbosa (l.) Link. & Khetpapra & Rubiaceae & Whole plant & $\mathrm{HD}, \mathrm{Rf}$ \\
\hline 38 & Helianthus annus L. & Surjamukhi & Asteraceae & Seeds, Roots, Leaves & SD, CD, DTD \\
\hline 39 & Ipomoea quamocli & Tarulata, Kamalata & Convolvulaceae & Whole plant & $\mathrm{PB}, \mathrm{AC}$ \\
\hline 40 & Ixora arborea roxb. & Shet Rangan & Rubiaceae & Root, Bark, Flower & $\mathrm{GD}, \mathrm{An}$ \\
\hline 41 & Jasminum scandens vahl. & Muichchaludi & Oleaceae & Roots & $\mathrm{SD}, \mathrm{ED}$ \\
\hline 42 & Jatropha curcas L. & Ban Verenda, Chanda & Euphorbiaceae & Seed, Sap & RH, DTD, PB \\
\hline 43 & Kalanchoe pinnata (lam.) Pers. & Patharkuchi & Crassulaceae & Leaves & RP, DTD, HD \\
\hline 44 & Lawsonia inermis L. & Mehedi, Mendi & Lythrac & Leaves, Bark & $\mathrm{BP}, \mathrm{RH}, \mathrm{SD}, \mathrm{ND}$ \\
\hline 45 & Leonurus sibiricus L. & Guma, Juma & Lamiaceae & Leaves & GD, PB \\
\hline 46 & Coccinia grandis $($ L.) & Telakochu & Cucurbitaceae & Whole plant & $\mathrm{GD}, \mathrm{ND}, \mathrm{SD}, \mathrm{Db}$ \\
\hline 47 & Nodiflora (l.) Greene phyla. & Koi okra & Verbenaceae & Leaves & $\mathrm{Rf}$ \\
\hline 48 & Terminalia arjuna. & Arjun & Combretaceae & Bark. Seed, Fruit & $\begin{array}{l}\text { CD, HD, STD, } \\
\text { DTD }\end{array}$ \\
\hline 49 & Terminalia belerica & Bohera & Combretaceae & Bark. Seed, Fruit & $\begin{array}{l}\text { CD, HD, STD, } \\
\text { DTD. }\end{array}$ \\
\hline 50 & Terminalia chebula & Horitok & Combretaceae & Bark. Seed, Fruit & $\mathrm{CD}, \mathrm{HD}, \mathrm{DTD}$ \\
\hline 51 & Clerodendrum viscosum Vent. & Vaidir gach & Lamiaceae & Leaves & $\mathrm{RP}$ \\
\hline 52 & Aloe barbadensis Mill. & Ghritakumari, & Liliaceae & Whole plant & DT, BP \\
\hline 53 & Alstonia scholaris $(\mathrm{L})$. & Chaitan & Apocynaceae & Bark & GD \\
\hline 54 & Mangifera indica & Aum & Anacardiaceae & Seed & $\mathrm{Db}$ \\
\hline 55 & Syzygium cumini (L.) & Jam & Myrtaceae & Fruit, Bark, Seed & $\mathrm{Db}, \mathrm{SD}, \mathrm{DTD}$ \\
\hline
\end{tabular}

ND = Neurological disorder; CD = Cardiovascular disorder; DTD = Digestive Track disorder; HD = Hepatic disorder; RD = Renal disorder $\mathrm{AA}=$ Anti Allergies; MSD = Muscular/Skeleton disorder; ED = Eye Problem; GD = Gynaecological disorder; RP $=$ Respiratory Problems; $\mathrm{AC}=$ Anti cancer; $\mathrm{AF}=$ Antifungal $; \mathrm{An}=$ Anaemia $; \mathrm{AP}=$ Anti-parasite $; \mathrm{Db}=$ Diabetes $; \mathrm{SD}=\mathrm{Skin}$ disorder; $\mathrm{PP}=\mathrm{Pain}$ problem; $\mathrm{BP}=\mathrm{Burn}$ problem; STD = Sexual transmitted diseases; RH = Reproductive health; Vitc-d = Vit-c deficiency; Rf = Rheumatic fever 


\section{Discussion and Recommendation}

The components of folk medicine as a healing modality, has long been ignored by medical practitioners for various reasons. The first and foremost reason is that many medicinal plants used by folk medicinal practitioners remain to be investigated through modern scientific methods. The relevant photochemical need to be identified and proper evaluations need to be made on their mode of action and possible toxicities. The second reason is an inherent distrust on supposedly 'ancient' modes of treatment, which many modern medical practitioners believe to be a combination of superstitious beliefs and placebo effects. On the other hand, more and more modern research is validating the use of medicinal plants, which are used by traditional medicinal practitioners throughout the world for treatment of various ailments. Syzygium cumini (L.) Skeels, used by the Kavirajes for treatment of diabetes is one example of a medicinal plant obtained in the present survey where scientific research is validating its use by the Kavirajes. Hypoglycemic effect has been reported of defatted seeds and water soluble fiber from the seeds of this plant in alloxan-induced diabetic rats (Pandey and Khan, 2002). The ethanolic extract of seeds of this plant also reportedly increased body weight and decreased blood sugar level in alloxaninduced diabetic albino rats. The extract also demonstrated improvement in the histopathology of pancreatic islets (Singh and Gupta, 2007). Antidiabetic, therapeutic and anti-oxidative effects have also been reported for an ethereal fraction of ethanolic extract of seed of the plant in streptozotocin induced diabetes in male rats (Mandal et al., 2008).

The potential value of the knowledge of traditional folk medicinal practitioners and their use of medicinal plants should not be underestimated. A recent review has shown that approximately $25 \%$ of modern medications have been plant derived, while $75 \%$ of new drugs against infectious diseases that have arrived between 1981 and 2002 originated from natural sources (Bedoya et al., 2009). Several bioactive phytochemical from plant sources like curcumin, resveratrol, baicalein, boswellic acid, betulinic acid, ursolic acid and oleanolic acid are now studied as possible drugs for the future against inflammatory diseases (Gautam and Jachak, 2009). Anti-cancer agents from plant sources currently being used or undergoing clinical trials include vinblastine, vincristine, nevelbine, etoposide, teniposide, taxol, taxotere, topotecan and irinotecan (Wang, 1998). Taken together, all available reports indicate that knowledge about the traditional use of plants must not be ignored. The folk medicinal practitioners of Bangladesh have been practicing and using medicinal plants in their practices from time immemorial. As such, cumulatively, they possess a vast store-house of medicinal plant knowledge. The present survey thus presents an enormous potential for further scientific studies to be carried out on the plants reported.

It is expected that these studies can lead to discovery of some compounds, which in turn can be a tool for development of better drugs. Moreover, if scientific studies validate the use of medicinal plants by the Kavirajes, that would present further impetus towards conservation of these plants, which are rapidly becoming endangered in their wild habitat.

\section{References}

Bedoya L. M.; Bermejo, P. and Abad, M. J. 2009; Anti-infectious activity in the Cistaceae family in the Iberial Peninsula; Mini Reviews in Medicinal Chemistry, 9(5):519-525

Cotton, C. M. 1996. Ethnobotany: Principle and Application, John Wiley and Sons, New York, pp: 399

Gautam, R. and Jachak, S. M. 2009. Recent developments in anti-inflammatory natural products; Medicinal Research Reviews, 29(5):767-820.

Hanif, A.; Hossan, M. S.; Mia, M. M. K.; Islam, M. J.; Jahan, R. and Rahmatullah, M. 2009. Ethnobotanical survey of the Rakhain tribe inhabiting the Chittagong Hill Tracts region of Bangladesh; American Eurasian journal of Sustainable Agriculture, 3(2):172-180

Hossan, M. S.; Shahadat, M.; Hanif, A.; Khan, M.; Bari, S.; Jahan, R. and Rahmatullah, M. 2009. Ethnobotanical survey of the Tripura tribe of Bangladesh. American Eurasian journal of Sustainable Agriculture, 3(2):253-261

Mandal, S.; Barik, B.; Mallick, C.; De, D. and Ghosh, D. 2008. Therapeutic effect of ferulic acid, an ethereal fraction of ethanolic extract of seed of Syzygium cumini against streptozotocin-induced diabetes in male rat. Methods and Findings in Experimental and Clinical Pharmacology, 30:121-128 
Martin, G. J. 1995. Ethnobotany: a 'People and Plants' Conservation Manual, Chapman and Hall, London, 268

Maundu, P. 1995. Methodology for collecting and sharing indigenous knowledge: a case study. Indigenous Knowledge and Development Monitor, 3:3-5

Mollik, M.A.H.; Hossan, M.S.; Paul, A.K.;. Rahman, M.T.; Jahan, R. and. Rahmatullah, M. 2010; A comparative analysis of medicinal plants used by folk medicinal healers in three districts of Bangladesh and inquiry as to mode of selection of medicinal plants. Ethnobotany Research and Applications, 8:195-218

Nawaz, A. H. M. M.; Hossain, M.; Karim, M.; Khan, M.; Jahan, R. and Rahmatullah M. 2009. An ethnobotanical survey of Rajshahi district in Rajshahi division, Bangladesh; American Eurasian journal of Sustainable Agriculture, 3:143-150

Pandey, M. and Khan, A. 2002. Hypoglycaemic effect of defatted seeds and water soluble fibre from the seeds of Syzygium cumini (Linn.) Skeels in alloxan diabetic rats; Indian Journal of Experimental Biology, 40:1178-1182

Rahmatullah, M.; Das, A. K.; Mollik, M. A. H.; Jahan, R.; Khan, M.; Rahman, T. and
Chowdhury, M.H. 2009. An ethnomedical survey of Dhamrai subdistrict in Dhaka district, Bangladesh. American Eurasian journal of Sustainable Agriculture, 3:881-888

Rahmatullah, M.; Hossan, M. S.; Hanif, A.; Roy, P.; Jahan, R.; Khan, M.; Chowdhury, M. H. and Rahman, T., 2010. Ethnomedicinal applications of plants by the traditional healers of the Marma tribe of Naikhongchhari, Bandarban District, Bangladesh. Adv. Nat. Appl. Sci., 3:392-401

Rahmatullah, M.; Noman, A.; Hossan, M.S.; Rashid, M.H.; Rahman, T.; Chowdhury, M.H. and Jahan, R. 2010. A survey of medicinal plants in two areas of Dinajpur district, Bangladesh including plants which can be used as functional foods. American Eurasian journal of Sustainable Agriculture, 3:862-876

Singh, N. and Gupta, M. 2007; Effect of ethanolic extract of Syzygium cumini (Linn.) seed powder on pancreatic islets of alloxan diabetic rats; Indian Journal of Experimental Biology, 45:861-867

Wang, H.K. 1998. Plant-derived anticancer agents currently in clinical use or in clinical trials, Investigational Drugs, 1(1): 92102 